\title{
KONTYNGENTY WOJSKA POLSKIEGO W MIĘDZYNARODOWYCH OPERACJACH POKOJOWYCH I STABILIZACYJNYCH PROWADZONYCH POD PRZYWÓDZTWEM STANÓW ZJEDNOCZONYCH*
}

\author{
POLISH MILITARY CONTINGENTS IN INTERNATIONAL \\ STABILIZATION AND PEACE OPERATION CONDUCTED \\ UNDER THE UNITED STATES' LEADERSHIP
}

Dariusz Kozerawski**

\begin{abstract}
ABSTRAKT
$-$

W niniejszym opracowaniu zostały przedstawione zagadnienia dotyczące zaangażowania polskich kontyngentów wojskowych w międzynarodowe operacje pokojowe i stabilizacyjne prowadzone pod przywództwem Stanów Zjednoczonych. Przybliżone zostały zadania, stan zaangażowania ilościowego $\mathrm{w}$ te operacje przed i po akcesji Polski do NATO. Ponadto wskazane zostały szanse i zagrożenia strategiczne wynikające $z$ udziału Sił Zbrojnych RP w operacjach kierowanych przez USA. Należy dodać, iż znacząca część opinii autora została oparta na wynikach badań terenowych prowadzonych w strefach działań wojennych oraz stabilizacyjnych podczas operacji stabilizacyjnych na Bałkanach (Bośnia
\end{abstract}

In the elaboration, problems concerning Polish Military Contingents' participation in international peace and stabilization operations conducted under the United States' leadership were introduced. The tasks, assignment range and quantitative scale of Polish participation in peace support operations were introduced before and after joining NATO by Poland. Besides, the strategic chances and threats were indicated in aspect of the participation of Polish Armed Forces in operations led by the USA. Additionally, the significant part of the author's opinion was based on the field researches in zones of war-activities and areas of stabilization during the NATO operation in Balkans (Bosnia and Herzegovina, Kosovo),

* Badania terenowe prowadzone były w formie badań społecznych jakościowych i ilościowych oraz metodą obserwacji uczestniczącej w kilku strefach odpowiedzialności polskich kontyngentów wojskowych (Bośnia i Hercegowina 1998-1999; Irak 2008, 2014; Afganistan 2009, 2012; Kosowo 2012).

** Uniwersytet Jagielloński w Krakowie, Wydziału Studiów Międzynarodowych i Politycznych. 
i Hercegowina, Kosowo), w Afganistanie i Iraku - prowadzonych pod przywództwem Stanów Zjednoczonych.

Słowa kluczowe: polskie kontyngenty wojskowe; operacje pokojowe; operacje stabilizacyjne; przywództwo USA; szanse i zagrożenia strategiczne in Afghanistan and Iraq - conducted under the United States' leadership.

Keywords: Polish Military Contingents; peace operations; stabilization operations; United States' leadership; strategic chances and threats

\section{WPROWADZENIE}

Początek ostatniej dekady XX w., obok rozpadu dwublokowego podziału świata, przyniósł znaczący wzrost liczby regionalnych i lokalnych konfliktów zbrojnych'. Próby ich rozwiązania lub ograniczania podejmowane przez społeczność międzynarodową na forum Organizacji Narodów Zjednoczonych najczęściej skutkowały powoływaniem komisji kontroli i nadzoru oraz misji obserwacyjnych ${ }^{2}$, a następnie kolejnych operacji pokojowych ${ }^{3}$, w części których uczestniczyły również polskie kontyngenty wojskowe. Obok kontynuowanej już od lat 70. operacji UNDOF w Syrii, pododdziały polskie uczestniczyły w działaniach pokojowych prowadzonych w Zatoce Perskiej, Kambodży, Libanie, na Haiti oraz w byłej Jugosławii. Z kolei początek nowego stulecia i związane z nim wyzwania bezpieczeństwa spowodował konieczność zaangażowania społeczności mię-

1 Zmiany charakteru i intensywności konfliktów zbrojnych lat dziewięćdziesiątych (szczególnie tych wewnątrzpaństwowych) i związane z nimi akty przemocy (akty ludobójstwa, „czyszczenie etniczne”, stosowanie taktyki „spalonej ziemi”, eksterminacja w obozach jenieckich lub obozach uchodźców, gwałty na tle narodowym, etnicznym lub religijnym, połączone z diametralną zmianą stosunku walczących stron do personelu międzynarodowych sił pokojowych i stabilizacyjnych stawiały przed tymi ostatnimi całkowicie nowe wyzwania, z którymi społeczność międzynarodowa nie zawsze potrafiła sobie skutecznie radzić, szerzej zob. Kozerawski (2012, ss. 157 i nast.).

2 Polski personel wojskowy już od 1953 roku uczestniczył w komisjach kontroli i nadzoru w Korei i Indochinach (Komisja Nadzorcza Państw Neutralnych w Korei 1953-1973; Międzynarodowe Komisje Nadzoru i Kontroli w Indochinach 1954-1969), a następnie w misji obserwacyjnej w Nigerii (Międzynarodowa Grupa Obserwatorów w Nigerii 1968-1970). W misjach tego typu brał udział nieuzbrojony personel wojskowy, co miało potwierdzać neutralny charakter wykonywanych działań obserwacyjnych.

3 Operacja pokojowa - to zespół działań podejmowanych przez podmioty stosunków międzynarodowych w celu zapobiegania, przerywania, łagodzenia, ograniczania lub wygaszania konfliktów zbrojnych o charakterze międzypaństwowym (międzynarodowym) lub wewnętrznym poprzez interwencję sił pokojowych posiadających mandat organizacji międzynarodowej na przywrócenie i utrzymanie pokoju w rejonie sytuacji kryzysowej, Kozerawski (2012, s. 42). 
dzynarodowej w operacje stabilizacyjne w ramach tzw. wojny z terroryzmem ${ }^{4}$. W okresie tym polskie kontyngenty wojskowe brały udział $w$ takich operacjach w Afganistanie i Republice Iraku prowadzonych pod przywództwem polityczno-militarnym Stanów Zjednoczonych.

W niniejszym artykule zostały przedstawione zagadnienia dotyczące zaangażowania polskich kontyngentów wojskowych w międzynarodowe operacje pokojowe i stabilizacyjne prowadzone pod przywództwem Stanów Zjednoczonych. Przybliżone zostały zadania, stan zaangażowania ilościowego w te operacje przed i po akcesji Polski do NATO. Ponadto wskazane zostały szanse i zagrożenia strategiczne wynikające $z$ udziału Sił Zbrojnych RP w operacjach kierowanych przez USA. Na szczególne podkreślenie zasługuje to, iż znacząca część opinii autora została oparta na wynikach badań terenowych prowadzonych w strefach działań wojennych oraz stabilizacyjnych podczas operacji stabilizacyjnych na Bałkanach (Bośnia i Hercegowina, Kosowo), w Afganistanie i Iraku, prowadzonych pod przywództwem Stanów Zjednoczonych.

Inicjatywy międzynarodowe podejmowane w celu przeciwdziałania, przerwania, dalszej eskalacji oraz zmniejszania konsekwencji konfliktów zbrojnych o różnej skali i intensywności podejmowane były z różnym skutkiem. Włączanie się w proces utrzymania bezpieczeństwa międzynarodowego Organizacji Narodów Zjednoczonych (od drugiej połowy XX wieku) wiązało się z prowadzeniem operacji pokojowych, które miały ograniczać lub zapobiegać eskalacji lokalnych i regionalnych konfliktów zbrojnych oraz wspierać poszkodowaną w nich ludność cywilną poprzez zapewnienie jej szeroko rozumianej pomocy humanitarnej. $Z$ kolei w ramach operacji stabilizacyjnych ${ }^{5}$ podejmowanych przez organizacje międzynarodowe lub koalicje państw (nie zawsze z poparciem/mandatem społeczności międzynarodowej) w celu utrzymania lub przywrócenia pokoju oraz obalenia władz nierespektujących zasady przestrzegania praw człowieka w rejonie konfliktu prowadzono również operacje o charakterze ofensywnym (bojowym).

4 Ataki terrorystyczne z 11 września 2001 roku na Word Trade Centre oraz Pentagon zapoczątkowały serię działań i operacji, które zadaniem Georga W. Busha miały być wymierzone w ich organizatorów oraz państwa wspierające międzynarodowy terroryzm.

5 Pojęcie operacje/działania stabilizacyjne jest rozumiane jako działania z użyciem komponentów sił zbrojnych, policyjnych, podejmowane przez organizacje międzynarodowe lub koalicje państw (nie zawsze z poparciem/mandatem społeczności międzynarodowej) w celu utrzymania lub przywrócenia pokoju oraz obalenia władz nierespektujących zasad przestrzegania praw człowieka w rejonie operacji (konfliktu) (Działania stabilizacyjne..., s. 7). 
Warto przypomnieć, iż w okresie pełnego uzależnienia władz PRL-u od Związku Radzieckiego nie prowadzono samodzielnej i niezależnej polityki zagranicznej, a siły zbrojne stanowiły część potencjału bojowego Układu Warszawskiego ${ }^{6}$. Aktywność kontyngentów Wojska Polskiego w ramach międzynarodowych operacji pokojowych w latach 1973-1989 ograniczała się do wykonywania zadań o charakterze logistycznym ${ }^{7}$. Na uwagę zasługuje również zapoczątkowanie procesu współdziałania z kanadyjskimi jednostkami logistycznymi podczas operacji UNEF II w Egipcie (1973), które następnie było kontynuowane w ramach operacji UNDOF w Syrii (od 1974) oraz UNTAG w Namibii (1989-1990). Należy podkreślić, iż w okresie tzw. zimniej wojny tego typu współpraca dwóch kontyngentów wojskowych państw z dwóch wrogich sobie bloków polityczno-militarnych miała miejsce po raz pierwszy ${ }^{8}$.

Na przełomie lat 80. i 90. XX w. rozpoczął się proces transformacji ustrojowej państwa polskiego, które stało się po raz pierwszy od zakończenia II wojny światowej w pełni suwerennym podmiotem w środowisku międzynarodowym. Władze polskie mogły podjąć trud samodzielnego określania interesów narodowych i celów strategicznych w obszarze bezpieczeństwa państwa (zewnętrznego i wewnętrznego). Świeżo odzyskana samodzielność w prowadzeniu własnej

${ }^{6}$ Należy podkreślić, iż wydzielone jednostki WP otrzymywały zadania w ramach planowanych operacji sojuszniczych i stanowiły część potencjału Układu Warszawskiego. Ze względu na pełne podporządkowanie polskich władz polityce Związku Radzieckiego, pozostałe struktury organizacyjne WP również były zobligowane do utrzymywania zdolności do wykonywania zadań o charakterze narodowym, jak i sojuszniczym.

$7 \mathrm{~W}$ omawianym okresie w ramach operacji pokojowych wykonywano głównie zadania operacyjne (np. takie jak: patrolowanie strefy rozdzielanie wojsk; obserwacja i monitorowanie przemieszczania wojsk i ludności cywilnej stron konfliktu, prowadzenie punktów kontrolnych na granicach państwowych i stref odpowiedzialności danej misji) oraz zadania logistyczne (np. takie jak: rozbudowa infrastruktury i fortyfikacji baz, punktów kontrolnych i punktów obserwacyjnych; pomoc medyczna; usługi transportowe; dowóz żywności i wody; serwisowanie i naprawa sprzętu oraz uzbrojenia; rozminowanie terenu). Do $1992 \mathrm{r}$. kontyngenty WP w ramach operacji pokojowych prowadzonych pod auspicjami ONZ wykonywały zadania o charakterze logistycznym.

8 Polska jako pierwsze państwo Układu Warszawskiego wysłała zwarty kontyngent wojskowy do udziału w operacji pokojowej UNEF II w 1973 roku. Wcześniej państwa bloku wschodniego - w pełni zależne politycznie i militarnie od Związku Radzieckiego - delegowały jedynie grupy nieuzbrojonych obserwatorów wojskowych. Należy podkreślić, iż mimo tego, że zarówno ZSRR, jak i USA w omawianym okresie nie wysyłały swoich kontyngentów do udziału w operacjach pokojowych, to poprzez ich pozycję stałych członków w Radzie Bezpieczeństwa ONZ oraz kluczowe role w sojuszach polityczno-militarnych takich jak NATO i UW, miały znaczący wpływ zarówno na skład narodowy poszczególnych operacji pokojowych, jak i na państwa sojusznicze, które obok działań pokojowych realizowały interesy swoich sojuszników i bloków polityczno-militarnych. 
polityki zagranicznej (niezależnej już od decyzji Kremla) miała również znaczący wpływ na podejmowanie w pełni suwerennych decyzji o udziale polskich kontyngentów wojskowych w operacjach pokojowych prowadzonych pod auspicjami ONZ oraz innych organizacji międzynarodowych.

Proces umacniania państwowości III RP w tamtym okresie sprowadzał się między innymi do?:

- zaangażowania we wprowadzanie, a następnie, utrwalanie demokracji i systemu gospodarki wolnorynkowej;

- dążenia do stopniowej integracji $\mathrm{w}$ wymiarze politycznym, gospodarczym, społecznym i militarnych z państwami Europy Zachodniej i bliskiej kooperacji ze Stanami Zjednoczonymi;

- prowadzenia działań patronalnych wobec mniejszych państw regionu (państwa bałtyckie Litwa Łotwa, Estonia);

- promowania demokracji wobec Ukrainy i Białorusi;

- rozwijania współpracy polityczno-wojskowej z państwami sąsiedzkimi (Niemcami, Litwą, Czechami, Słowacją, Ukrainą);

- zaangażowania w inicjatywy regionalne (Trójkąt Weimarski: Francja Niemcy - Polska, Grupa Wyszehradzka: Czechy - Polska - Węgry - Słowacja).

Do grupy zasadniczych celów strategicznych Polski w omawianym okresie $\mathrm{w}$ dziedzinie bezpieczeństwa należy zaliczyć ${ }^{10}$ : wzmacnianie własnego potencjału obronnego; ochronę i zapewnienie bezpieczeństwa narodowego państwa poprzez poszukiwanie nowych partnerów strategicznych na Zachodzie jako przeciwwagi dla ewentualnego neoekspansjonizmu Rosji; wypracowanie własnych koncepcji strategicznych bezpieczeństwa państwa (szczególnie istotnych w okresie samodzielności strategicznej RP w latach 1989-1999); spowodowanie wyprowadzenia $\mathrm{z}$ terytorium Polski wojsk radzieckich; zapewnienie bezpieczeństwa narodowego poprzez członkostwo w NATO i UE; rozwój dziedzin gospodarki dostarczających nowoczesnych zasobów i zdolności do zapewnienia bezpieczeństwa państwa; prowadzenie polityki międzynarodowej sprzyjającej wzmocnieniu bezpieczeństwa Polski i przyczyniającej się do kształtowania stabilnego i pokojowego środowiska międzynarodowego.

\footnotetext{
9 Szerzej zob.: Biała księga..., ss. 33-35; Kozerawski (2012, ss. 159-160).

10 Na podstawie materiałów z prac zespołu „Interesów narodowych i celów strategicznych” opracowywanych w ramach Strategicznego Przeglądu Bezpieczeństwa Narodowego objętego patronatem prezydenta RP, w których autor niniejszego opracowania twórczo uczestniczył w latach 2010-2012, szerzej zob. Biała księga..., s. 34 i nast.
} 
Należy jednocześnie podkreślić, iż w okresie tzw. zimnej wojny Polska była pierwszym i przez długie lata jedynym państwem bloku wschodniego biorącym tak częsty i aktywny udział w międzynarodowych operacjach pokojowych i wojskowych misjach obserwacyjnych. Uzyskiwane doświadczenia oraz poziom wykonywanych zadań mandatowych pozytywnie wpływały na wizerunek PRL-u jako państwa znacząco zaangażowanego w proces umacniania pokoju i bezpieczeństwa międzynarodowego, mimo braku samodzielności w prowadzeniu własnej polityki zagranicznej i bezpieczeństwa (Kozerawski, 2018, ss. 129 i nast.)

Polskie kontyngenty wojskowe w latach 90. ubiegłego wieku zaczęły brać udział w operacjach pokojowych i stabilizacyjnych na Bałkanach prowadzonych przez NATO pod auspicjami ONZ (IFOR, SFOR, KFOR) ${ }^{11}$, a następnie w Afganistanie i Iraku prowadzonych przez NATO (ISAF, NTMI) lub koalicje państw (Enduring Freedom - Afganistan; Iraqi Freedom - Irak) (Kozerwski, 2012, ss. 167-178; Kozerwski, 2010). Należy podkreślić, iż we wszystkich z wymienionych operacji międzynarodowych rolę państwa przewodzącego/wiodącego w wymiarze polityczno-militarnym (Lead Nation) odgrywały Stany Zjednoczone.

\section{ZADANIA POLSKICH KONTYNGENTÓW WOJSKOWYCH W OPERACJACH MIĘDZYNARODOWYCH POD PRZYWÓDZTWEM STANÓW ZJEDNOCZONYCH PRZED AKCESJĄ POLSKI W NATO}

Od 1951 roku miała miejsce ewolucja zadań wykonywanych przez żołnierzy i kontyngenty Wojska Polskiego ${ }^{12} \mathrm{w}$ operacjach pokojowych, a następnie stabilizacyjnych. W XX w. żołnierze Wojska Polskiego w ramach tych operacji międzynarodowych realizowali następujące zadania:

- obserwacyjne (1953-1973);

11 IFOR - Implementation Forces; SFOR - Stabilization Forces; KFOR - Kosovo Forces.

12 Należy podkreślić, iż udział jednostek Wojska Polskiego w inwazji wojsk Układu Warszawskiego na Czechosłowację w ramach operacji „Dunaj” w 1968 roku nie miał charakteru działań pokojowych i stabilizacyjnych, a wynikał z podporządkowania władz PRL polityce Związku Radzieckiego, potwierdzającej dominującą rolę tego państwa w stosunku do państw satelickich Europy ŚrodkowoWschodniej, pozostających w strefie wpływów tego mocarstwa. Operacja militarna wojsk Układu Warszawskiego na terytorium Czechosłowacji prowadzona pod przywództwem ZSRR nie była legitymizowana przez ONZ, jak to miło miejsce w stosunku do wszystkich innych operacji pokojowych, w których uczestniczyły kontyngenty WP w okresie tzw. zimnej wojny. 
- logistyczne i obserwacyjne (1973-1992);

- operacyjne, logistyczne i obserwacyjne (1992-2003);

- bojowe, operacyjne, szkoleniowo-doradcze, logistyczne i obserwacyjne (2003-2021).

W XXI wieku w latach 2003-2021 polscy żołnierze wykonywali poza zadaniami logistycznymi, obserwacyjnymi i operacyjnymi ${ }^{13}$ także zadania bojowe i szkoleniowo-doradcze. Te ostatnie - zadania bojowe i szkoleniowo-doradcze - związane były głównie z zaangażowaniem kontyngentów WP w operacje stabilizacyjne na terytorium Afganistanu i Iraku.

Zmiany ustrojowo-gospodarcze w Polsce zapoczątkowane w 1989 roku wiązały się również ze konkretnymi działaniami mającymi na celu integrację z zachodnimi strukturami bezpieczeństwa. W pełni niezależna polityka zagraniczna Rzeczypospolitej Polskiej przekładała się między innymi na:

- udział kontyngentów Wojska Polskiego w operacjach międzynarodowych prowadzonych pod przywództwem Stanów Zjednoczonych w Zatoce Perskiej (1991) i na Haiti (1994) ${ }^{14}$;

- przystąpienie i aktywne uczestnictwo w programie „Partnerstwo dla pokoju"15;

13 Do zasadniczych zadań operacyjnych wykonywanych przez polskie kontyngenty wojskowe od 1992 r. w ramach operacji pokojowych i stabilizacyjnych należy zaliczyć: nadzorowanie demilitaryzacji obszarów chronionych; kontrolowanie dostępu do strefy rozdzielenia przez utworzenie punktów kontrolnych; prowadzenie obserwacji i monitorowanie sytuacji przez wykorzystywanie punktów obserwacyjnych; patrolowanie wewnątrz własnej strefy odpowiedzialności lub wspólnie z innymi jednostkami w strefach poszczególnych kontyngentów narodowych; eskortowanie konwojów ze wsparciem logistycznym lub pomocą humanitarną; ochronę ludności cywilnej, uchodźców; przeszukiwanie miejscowości, obiektów; zatrzymywanie podejrzanych osób i zakazanych prawem towarów; nadzorowanie szkolenia wojsk stron konfliktu; nadzorowanie stanu posiadanego uzbrojenia i amunicji wojsk stron konfliktu.

14 Do głównych zadań jakie były wykonywane przez żołnierzy jednostki GROM stanowiących trzon kontyngentu WP (51 żołnierzy sił specjalnych na 55 uczestników tej operacji w składzie PKW) w ramach operacji pokojowej na Haiti należy zaliczyć: ochronę ważnych osób; nadzorowanie lokalnych sił policyjnych; patrolowanie strefy odpowiedzialności; ochronę ważnych obiektów. Z kolei do zasadniczych celów jakie zostały osiągnięte w wyniku udziału kontyngentu WP w ramach operacji pokojowej na Haiti należy zaliczyć: potwierdzenie politycznego zbliżenia Polski do Stanów Zjednoczonych i zachodnich struktur bezpieczeństwa (NATO); budowanie wizerunku RP jako suwerennego państwa aktywnie zaangażowanego w utrzymanie bezpieczeństwa w środowisku międzynarodowym; potwierdzenie możliwości skutecznej wojskowej współpracy polsko-amerykańskiej, która była następnie kontynuowana w kolejnych operacjach pokojowych i stabilizacyjnych (na Bałkanach, w Afganistanie, Iraku).

15 Pierwsze ćwiczenia w ramach programu „Partnerstwo dla Pokoju” w Polsce zostały przeprowadzone na poligonie w Biedrusku w 1994 roku. 
- udział w międzynarodowych operacjach wsparcia pokoju na Bałkanach (IFOR, SFOR, AFOR, KFOR) prowadzonych pod dowództwem NATO i auspicjami ONZ (1995-1999).

Ww. aktywności, które stanowiły praktyczne potwierdzenie dążeń władz RP do integracji z transatlantyckim systemem bezpieczeństwa zbiorowego, zostały ukoronowane 12 marca 1999 roku przystąpieniem Rzeczypospolitej Polskiej do Sojuszu Północnoatlantyckiego.

W okresie poprzedzającym polską akcesję do NATO kontyngenty WP wykonywały głównie zadania operacyjne i logistyczne na Bałkanach w ramach misji IFOR (1995-1996), SFOR (od1996), KFOR (od 1999) oraz logistyczne w ramach AFOR w Macedonii (1999). Należy podkreślić, iż kluczową rolę w ramach tych operacji wsparcia pokoju odgrywało polityczno-militarne przywództwo Stanów Zjednoczonych. Bez tak znaczącego zaangażowania tego supermocarstwa w wymiarze politycznym, ekonomicznym i militarnym (zarówno logistycznym, jak i operacyjnym) skuteczne prowadzenie działań pokojowych i stabilizacyjnych byłoby praktycznie niemożliwe. W tabeli 1 został przedstawiony zakres zaangażowania kontyngentów WP w operacje międzynarodowe prowadzone pod przywództwem USA.

Z analizy tabeli wynika, iż już od 1991 roku polskie kontyngenty wojskowe brały udział w operacjach pokojowych i stabilizacyjnych prowadzonych pod polityczno-militarnym przywództwem Stanów Zjednoczonych (w tym pod auspicjami ONZ), z których część była wykonywana przez Sojusz Północno-

Tabela 1. Zaangażowanie polskich kontyngentów wojskowych w operacjach międzynarodowych prowadzonych pod przywództwem Stanów Zjednoczonych w latach 1990-1999

\begin{tabular}{|c|c|c|c|c|c|}
\hline Lp. & Nazwa operacji & Rejon operacji & $\begin{array}{c}\text { Okres trwania } \\
\text { operacji }\end{array}$ & $\begin{array}{c}\text { Liczba } \\
\text { uczestników }\end{array}$ & Zadania \\
\hline 1 & Pustynna Burza & Zatoka Perska & 1991 & około 150 & $\begin{array}{c}\text { - logistyczne (pomoc } \\
\text { medyczna); } \\
\text { - ratownictwo morskie; } \\
\text { - prace remontowe; }\end{array}$ \\
\hline 2 & UNMIH* $^{*}$ & Haiti & 1994 & 55 & $\begin{array}{c}\text { - ochronne; } \\
\text { - patrolowe; }\end{array}$ \\
\hline 3 & IFOR & $\begin{array}{c}\text { Bośnia } \\
\text { i Hercegowina }\end{array}$ & 1996 & około 650 & - operacyjne \\
\hline 4 & SFOR & $\begin{array}{c}\text { Bośnia } \\
\text { i Hercegowina }\end{array}$ & $1996-1999$ & $430-490$ & - operacyjne \\
\hline
\end{tabular}




\begin{tabular}{|c|c|c|c|c|c|}
\hline Lp. & Nazwa operacji & Rejon operacji & $\begin{array}{c}\text { Okres trwania } \\
\text { operacji }\end{array}$ & $\begin{array}{c}\text { Liczba } \\
\text { uczestników }\end{array}$ & Zadania \\
\hline 5 & AFOR & Albania & 1999 & 140 & - logistyczne \\
\hline 6 & $\begin{array}{c}\text { Kosovo Forces }- \\
\text { PKW KFOR }\end{array}$ & Kosowo & od 1999 & około 220 & $\begin{array}{c}\text { - operacyjne; } \\
\text { - szkoleniowe; }\end{array}$ \\
\hline
\end{tabular}

* UNMIH - United Nation Mission to Haiti - Misja Narodów Zjednoczonych na Haiti.

Źródło: Opracowanie własne na podstawie: www.nato.int; www.mon.gov.pl; www.do.wp.mil.pl; www.gov.pl/web/obrona-narodowa/misje.

atlantycki (operacje na Bałkanach). Duża różnorodność realizowanych zadań (logistyczne, ochronne, operacyjne), skala polskiego zaangażowania, strefy działań mandatowych (Bliski Wschód, Haiti, Bałkany) oraz obszary współpracy militarnej z wojskami USA stanowiły z jednej strony potwierdzenie politycznej woli władz polskich do integracji z zachodnimi strukturami bezpieczeństwa, a z drugiej - cenne źródło doświadczeń wojskowych, które tworzyły solidną podstawę do dalszego rozwijania współpracy polsko-amerykańskiej po przystąpieniu Polski do NATO.

\section{ZADANIA WYKONYWANE PRZEZ POLSKIE KONTYNGENTY WOJSKOWE WE WSPÓŁPRACY Z WOJSKAMI AMERYKAŃSKIMI PO 1999 ROKU}

Kolejny ważny etap zaangażowania Polski w operacje międzynarodowe prowadzone pod przywództwem polityczno-militarnym Stanów Zjednoczonych ${ }^{16}$ obejmuje już okres po przystąpieniu Polski do Sojuszu Północnoatlantyckiego (12 marca 1999 r.), w którym polskie kontyngenty wojskowe wykonywały następujące rodzaje zadań:

- operacyjne podczas misji KFOR w Kosowie (od 1999);

- logistyczne w operacji koalicyjnej „Enduring Freedom” w Afganistanie (2002-2007);

- operacyjne, bojowe podczas operacji koalicyjnej „Iraqi Freedom” w Iraku (2003-2008) oraz operacji ISAF w Afganistanie (2007-20014);

16 Operacje międzynarodowe z wykorzystaniem komponentów wojskowo-cywilnych, prowadzone pod przywództwem polityczno-militarnym Stanów Zjednoczonych, miały charakter sojuszniczy (pod auspicjami NATO i ONZ) oraz koalicyjny (bez legitymizacji prowadzonych działań ze strony organizacji międzynarodowych). 
- szkoleniowe w ramach operacjach NTMI-I w Iraku (2005-2009) oraz NTMI-A w Afganistanie (2009-2014);

- kontroli przestrzeni powietrznej państw bałtyckich w ramach operacji „Baltic Air Policing” (od 2006 - udział rotacyjny);

- szkoleniowo-doradcze w ramach operacji „Resolute Support” w Afganistanie (2014-2021).

Należy dodać, iż żołnierze polscy brali również udział w realizacji zadań przez Korpus Północ-Wschód (którego sztab stacjonuje na terytorium Polski w Szczecinie), tworząc dowództwo operacji ISAF w Afganistanie prowadzonej pod auspicjami NATO. Ponadto żołnierze polskiego kontyngentu wojskowego wykonywali zadania (od 2002 roku) w ramach operacji koalicyjnej „Enduring Freedom" prowadzonej pod przywództwem polityczno-militarnym USA. Należy stwierdzić, iż w obu tych operacjach kluczową rolę w wymiarze politycznym i wojskowym odgrywały Stany Zjednoczone, z którymi między innymi współpracował personel wojskowo-cywilny polskich kontyngentów wojskowych na wszystkich szczeblach funkcjonalnych.

W roku 2021 Polska była lub jest zaangażowana w kilku operacjach Sojuszu Północnoatlantyckiego (np. „Resolute Support” w Afganistanie, KFOR w Kosowie, NTCB w Iraku, UNIFIL w Libanie, na Łotwie, w Rumunii). Szczegóły ww. aktywności dotyczącej współpracy polsko-amerykańskiej zostały zamieszczone $\mathrm{w}$ zestawieniu tabelarycznym poniżej.

Polskie kontyngenty wojskowe aktywnie uczestniczą w operacji wsparcia wschodniej flanki NATO w tym: na Łotwie ${ }^{17}$; operacji Orlik 8 - z udziałem rotacyjnym sił powietrznych oraz w Rumunii (ok. 200 żołnierzy biorących udział w ćwiczeniach i szkoleniu) ${ }^{18}$. Z kolei w 2017 roku na prośbę Sojuszu Polska podjęła się roli państwa wiodącego, które koordynuje misję szkolenia i budowania zdolności w Iraku NTCB-I ${ }^{19}$. We wszystkich tych operacjach mię-

17 Głównym element kontyngentu stanowi kompania czołgów PT-91 Twardy, która wchodzi w skład wielonarodowego batalionu NATO.

18 Zmienia się także charakter operacji na Łotwie i w Rumunii, gdzie Polacy nie wykonują zadań stabilizacyjnych lub szkoleniowych, lecz są gotowi do podjęcia działań bojowych w razie kryzysu i wojny, a na co dzień uczestniczą w intensywnych szkoleniach.

19 NTCB-I - NATO Training and Capacity Building Iraq. Głównym zadaniem sił międzynarodowych w ramach tej operacji jest szkolenie specjalistów, którzy w przyszłości będą naprawiać i utrzymywać poradziecki sprzęt pancerny, którego duże zapasy znajdują się nad Eufratem i Tygrysem. 
Tabela 2. Zaangażowanie polskich kontyngentów wojskowych w operacjach międzynarodowych prowadzonych pod przywództwem Stanów Zjednoczonych po przystąpieniu Polski do NATO

\begin{tabular}{|c|c|c|c|c|c|}
\hline Lp. & Nazwa operacji & Rejon operacji & $\begin{array}{l}\text { Okres trwa- } \\
\text { nia operacji }\end{array}$ & $\begin{array}{c}\text { Liczba } \\
\text { uczestników }\end{array}$ & Zadania \\
\hline 1 & $\begin{array}{c}\text { Kosovo Forces - PKW } \\
\text { KFOR }\end{array}$ & Kosowo & od 1999 & około 220 & $\begin{array}{l}\text { - operacyjne; } \\
\text { - szkoleniowe; }\end{array}$ \\
\hline 2 & Amber Fox & Macedonia & 2001-2002 & 25 & - operacyjne \\
\hline 3 & Allied Harmony & Macedonia & $2002-2003$ & 25 & - operacyjne \\
\hline 4 & Enduring Freedom & Afganistan & $2002-2007$ & około 100 & - logistyczne \\
\hline 5 & Iraqi Freedom & Irak & $2003-2008$ & $2500-900$ & $\begin{array}{l}\text { - operacyjne; } \\
\text { - bojowe; }\end{array}$ \\
\hline 6 & $\begin{array}{c}\text { Baltic Air Policing - PKW } \\
\text { Orlik } 8\end{array}$ & $\begin{array}{l}\text { Estonia, Litwa, } \\
\text { Łotwa, }\end{array}$ & $\begin{array}{c}\text { Od 2006; } \\
\text { w 2021 } \\
\text { - (udział } \\
\text { rotacyjny) }\end{array}$ & około 140 & $\begin{array}{c}\text { - kontrola przestrzeni } \\
\text { powietrznej państw } \\
\text { bałtyckich; }\end{array}$ \\
\hline 7 & ISAF & Afganistan & $2007-2014$ & $1400-2600$ & $\begin{array}{l}\text { - operacyjne; } \\
\text { - bojowe; }\end{array}$ \\
\hline 8 & $\begin{array}{c}\text { „Resolute Support” - PKW } \\
\text { Afganistan }\end{array}$ & Afganistan & od 2015 & $\begin{array}{c}\text { około } \\
350-400\end{array}$ & $\begin{array}{l}\text { - szkoleniowo- } \\
\text {-doradcze; }\end{array}$ \\
\hline 9 & $\begin{array}{l}\text { PKW Irak „Inherent } \\
\text { Resolve” }\end{array}$ & Irak, Katar, Kuwejt & Od 2017 & Około 350 & $\begin{array}{c}\text { - szkolenie irackich } \\
\text { żołnierzy w zakresie na- } \\
\text { praw sprzętu produkcji } \\
\text { radzieckiej }\end{array}$ \\
\hline 10 & PKW Rumunia & Rumunia, Bułgaria & od 2017 & około 230 & $\begin{array}{l}\text { - wsparcie wschodniej } \\
\text { flanki NATO - ćwiczenia } \\
\text { sojusznicze, szkolenie; }\end{array}$ \\
\hline 11 & $\begin{array}{c}\text { SNMCMG1 - Stały Zespół } \\
\text { Sił Morskich Grupa } 1 \text { - } \\
\text { PKW Puławski* }\end{array}$ & Morze Śródziemne & $\begin{array}{l}1.02-30.06 \\
2019 \mathrm{r} .\end{array}$ & około 230 & $\begin{array}{l}\text { przeciwdzia-łanie terro- } \\
\text { ryzmowi na morzu oraz } \\
\text { wspieranie budowania } \\
\text { zdolności w zakresie bez- } \\
\text { pieczeństwa morskiego }\end{array}$ \\
\hline 12 & PKW Łotwa & Łotwa & od 2017 & około 170 & $\begin{array}{l}\text { - wsparcie wschodniej } \\
\text { flanki NATO - ćwiczenia } \\
\text { sojusznicze, szkolenie; }\end{array}$ \\
\hline 13 & $\begin{array}{c}\text { Polski Kontyngent } \\
\text { Wojskowy w ramach } \\
\text { Dostosowanych Środków } \\
\text { Wzmocnienia Organizacji } \\
\text { Traktatu Północnoatlan- } \\
\text { tyckiego dla Turcji }\end{array}$ & $\begin{array}{c}\text { Turcja (na } \\
\text { terytorium } \\
\text { Turcji, wschodnim } \\
\text { akwenie Morza } \\
\text { Śródziemnego oraz } \\
\text { Morzu Czarnym) }\end{array}$ & od 2020 & około 80 & $\begin{array}{l}\text { - rozpoznawcze, } \\
\text { - patrolowe; }\end{array}$ \\
\hline
\end{tabular}

* ORP „Gen. K. Pułaski” wykonywał zadania operacyjne w składzie zespołu już w 2006 oraz 2008 roku.

Źródło: Opracowanie własne na podstawie: www.nato.int; www.mon.gov.pl; www.do.wp.mil.pl; www.gov. $\mathrm{pl} /$ web/obrona-narodowa/misje. 
dzynarodowych żołnierze polscy współpracowali lub współpracują z personelem wojskowo-cywilnym komponentów wojskowych USA na różnych szczeblach funkcjonalnych.

\section{FINANSOWANIE UDZIAŁU POLSKICH KONTYNGENTÓW WOJSKOWYCH W MIĘDZYNARODOWYCH OPERACJACH POKOJOWYCH I STABILIZACYJNYCH}

Istotnym elementem funkcjonowania polskich kontyngentów wojskowych w międzynarodowych operacjach pokojowych i stabilizacyjnych pod przywództwem Stanów Zjednoczonych jest ich finansowanie, a szczególnie ta jego część, która pochodziła z budżetu Ministerstwa Obrony Narodowej. W tabeli poniżej przedstawione zostały wydatki budżetowe dotyczące kontyngentów WP w operacjach pokojowych prowadzonych pod auspicjami NATO, UE, ONZ oraz pod przywództwem Stanów Zjednoczonych.

Należy podkreślić, iż w części dostępnych źródeł wiedzy wydatki na operacje Iraqi Freedom (2003-2008) szacowane są na ponad 1 mld zł, a wydatki poniesione na udział kontyngentu WP $\mathrm{w}$ operacji Enduring Freedom a następnie

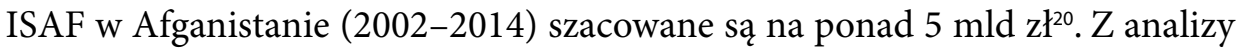
zamieszczonego powyżej zestawienia tabelarycznego wynika, iż największym obciążeniem dla budżetu państwa były operacje w Afganistanie w latach 2002-2014 (koszt około 4,8 mld zł) oraz operacja stabilizacyjna w Iraku (około 1 mld zł). Przyczyn takiego stanu rzeczy należy szukać w: długim okresie trwania tych operacji; specyfice zadań bojowych wykonywanych w ich trakcie; liczbie uczestniczących żołnierzy WP (do około $2500 \mathrm{w}$ ramach jednej zmiany); liczbie jednostek sprzętu wykorzystywanego na ww. teatrach działań stabilizacyjnych, wydłużonych liniach zaopatrywania logistycznego (lądowych, powietrznych i morskich).

Interesujących wniosków dostarcza również analiza porównawcza wskaźnika dotyczącego średniorocznych wydatków z budżetu MON. Uśrednione wydatki w wymiarze rocznym w Afganistanie ponad dwukrotnie przewyższały te z Iraku i blisko dziesięciokrotnie koszty funkcjonowania operacji NATO w Kosowie. Z kolei średnioroczny koszt dwóch operacji pokojowych ONZ w Syrii i Libanie

20 Zob. Polska misja w Afganistanie pochłonęła pięć miliardów złotych. Money.pl. 
Tabela 3. Wydatki z budżetu Ministerstwa Obrony Narodowej na funkcjonowanie polskich kontyngentów wojskowych w wybranych międzynarodowych operacjach pokojowych i stabilizacyjnych

\begin{tabular}{|c|c|c|c|c|c|}
\hline Lp. & Nazwa operacji & $\begin{array}{c}\text { Okres } \\
\text { finansowania* }\end{array}$ & $\begin{array}{c}\text { Miejsce /organi- } \\
\text { zacja/ państwo } \\
\text { wiodące }\end{array}$ & $\begin{array}{c}\text { Wydatki budże- } \\
\text { towe MON } \\
\text { [mln zl] }\end{array}$ & $\begin{array}{c}\text { Wydatki } \\
\text { średnioroczne } \\
\text { [mln zl] }\end{array}$ \\
\hline 1 & Iraqi Freedom & $2003-2009$ & Irak/ USA & 983,2 & 140,5 \\
\hline 2 & $\begin{array}{c}\text { Enduring Freedom } \\
\text { ISAF }\end{array}$ & $2002-20014$ & $\begin{array}{c}\text { Afganistan/USA } \\
\text { /NATO }\end{array}$ & $4.792,7$ & 368,7 \\
\hline 3 & Resolute Suppot & $2015-31.03 .2021$ & $\begin{array}{c}\text { Afganistan/USA } \\
\text { /NATO }\end{array}$ & 370 & 46,3 \\
\hline 3 & PKW KFOR & $1999-2012$ & Kosowo/ NATO & 514 & 36,7 \\
\hline 4 & $\begin{array}{c}\text { PKW UNDOF } \\
\text { PKW UNIFIL }\end{array}$ & $2007-2010^{* *}$ & Syria, Liban/ ONZ & 145,2 & 36,3 \\
\hline 5 & PKW Czad & $2007-2010$ & Czad/ UE & 262,2 & 65,6 \\
\hline 6 & PKW Kongo & $2006-2007$ & Kongo/ UE & 10,8 & 5,4 \\
\hline
\end{tabular}

* Należy zaznaczyć, iż okres finansowania danej operacji podany w tabeli 3 nie w każdym przypadku odpowiada okresowi jej formalnego trwania, gdyż wydatki z budżetu MON były ponoszone na poszczególne misje jeszcze po jej oficjalnym zakończeniu.

** Oficjalnie Polska wycofała swoje kontyngenty z operacji UNDOF w Syrii i UNIFIL w Libanie w 2009 roku, ale wydatki ponoszone były jeszcze w roku 2010.

Źródło: Opracowanie własne na podstawie: Dowództwo Operacyjne, MON, Warszawa 2015; money. pl; www.mon.gov.pl.

był porównywalny do średnich rocznych wydatków z budżetu MON na operacje NATO w Kosowie oraz w Afganistanie (Resolute Support). Ten stan rzeczy wynikał z procedur ONZ, sprowadzających się do zwrotu części kosztów państwom członkowskim wysyłającym swoje kontyngenty do udziału w operacjach pokojowych prowadzonych pod auspicjami tej organizacji międzynarodowej. Z kolei średnioroczny koszt operacji prowadzonych pod auspicjami Unii Europejskiej przyjmował różne wartości, w zależności od: specyfiki zadań, liczby żołnierzy i sprzętu, lokalizacji stref odpowiedzialności kontyngentów WP w tych działaniach, linii zaopatrywania logistycznego. Nawiązując do tematyki niniejszego artykułu, należy podkreślić, iż koszty ogólne, jak i te średnioroczne ponoszone z budżetu MON na udział polskich kontyngentów wojskowych w operacjach stabilizacyjnych, były najwyższe w odniesieniu do misji prowadzonych pod przywództwem Stanów Zjednoczonych (w Afganistanie i Iraku). 


\section{ZAGROŻENIA STRATEGICZNE}

Zaangażowanie kontyngentów Wojska Polskiego w ramach operacji międzynarodowych prowadzonych pod przywództwem polityczno-militarnym Stanów Zjednoczonych wiąże się z licznymi zagrożeniami strategicznymi ${ }^{21}$, między innymi takimi jak:

1. Różnice w postrzeganiu priorytetów polityki bezpieczeństwa wśród państw uczestniczących w danej operacji a Stanami Zjednoczonymi $\mathrm{w}$ wymiarze narodowym i międzynarodowym, wynikające $\mathrm{z}$ różnych partykularnych interesów tego supermocarstwa (np. na Bałkanach, Bliskim Wschodzie i Azji Centralnej);

2. Rozbieżności między ambicjami/interesami państw biorących udział w operacjach $\mathrm{z}$ ich realnymi możliwości/zdolnościami (politycznymi, ekonomicznymi, militarnymi) oraz interesami USA ${ }^{22}$;

3. Różnice w poziomie realnych zdolności militarnych poszczególnych zmian polskich kontyngentów wojskowych związane z praktycznym obniżaniem stopnia interoperacyjności - wynikające $\mathrm{z}$ faktu braku bezpośredniego zaangażowania tych pododdziałów we wspólne operacje wielonarodowe o charakterze bojowym;

4. Reaktywacja zadawnionych lub eskalacja istniejących konfliktów zbrojnych na tle religijnym, narodowo-etnicznym, politycznym, gospodarczym ${ }^{23}$;

5. Problemy w formułowaniu priorytetów polityki bezpieczeństwa państwa granicznego Sojuszu wynikające $\mathrm{z}$ nadmiernego zaangażowania $\mathrm{w}$ operacje międzynarodowe, $\mathrm{z}$ których znacząca większość była i jest prowadzona pod przywództwem polityczno-militarnym USA ${ }^{24}$.

21 Zagrożenia strategiczne - pośrednie lub bezpośrednie destrukcyjne oddziaływania na podmiot bezpieczeństwa, najbardziej klasyczny czynnik środowiska bezpieczeństwa, Biała księga bezpieczeństwa narodowego RP, Warszawa 2013, s. 248.

22 Przykładami ww. zjawiska mogą być aktywności o charakterze gospodarczo-społecznym Stanów Zjednoczonych na terytorium Afganistanu podczas operacji ISAF, „Enduring Freedom”, operacji „Iraqi Freedom”, czy w Kosowie podczas operacji KFOR - związane z realizacją własnych interesów narodowych.

23 Przykładem obrazującym ww. zagrożenie może być eskalacja konfliktu zbrojnego na terytorium Afganistanu po likwidacji operacji ISAF i wycofaniu większości sił operacyjnych. Funkcjonująca tam od 2015 roku operacja szkoleniowo-doradcza „Resolute Support” ma wymiar wizerunkowo-polityczny, nie odgrywając większej roli w procesie kształtowania sytuacji bezpieczeństwa w regionie. Między innymi $\mathrm{z}$ tych względów prezydent Joe Biden zadeklarował wycofanie sił amerykańskich $\mathrm{z}$ tego państwa do końca 2021 roku.

24 Przykładem takich dylematów była dyskusja nad wyborem strategicznych kierunków rozwi- 
6. Zaangażowanie $\mathrm{w}$ operacje $\mathrm{z}$ użyciem komponentów wojskowych (w krótko- i średnioterminowej perspektywie strategicznej) bez określenia/uwzględnienia ich realistycznego finalnego skutku w wymiarze nie tylko militarnym, ale przede wszystkim politycznym, społecznym i ekonomicznym ${ }^{25}$ (np. ISAF);

7. Procedura decyzyjna dotycząca angażowania Sił Zbrojnych RP w operacje wielonarodowe pod przywództwem Stanów Zjednoczonych o charakterze typowo bojowym, warunkująca w późniejszym okresie znaczący spadek poparcia społecznego dla prowadzonych działań w rejonie konfliktu;

8. Straty wśród ludności lokalnej wynikające z tzw. błędów militarnych w rejonie konfliktu obciążających między innymi państwa uczestniczące (np. Enduring Freedom, ISAF - Afganistan);

9. Jednostronna i bezrefleksyjna polityka władz dotycząca relacji polsko-amerykańskich przekładająca się na zaangażowanie polskich kontyngentów wojskowych oraz jego skalę na korzyść USA - nierzadko kosztem relacji z innymi państwami sojuszniczymi, bez konkretnych korzyści strony polskiej w wymiarze polityczny, ekonomicznym, społecznym lub militarnym.

\section{SZANSE STRATEGICZNE}

Aktywne zaangażowanie Polski w operacje pokojowe i stabilizacyjne prowadzone pod przywództwem Stanów Zjednoczonych może również kreować szanse strategiczne ${ }^{26}$, do których między innymi można zaliczyć:

jania zdolności Sił Zbrojnych RP.W pierwszej dekadzie XXI w. koncentrowano się na priorytetowym traktowaniu zdolności ekspedycyjnych, związanych z udziałem kilkutysięcznych kontyngentów WP w operacjach w Afganistanie i Iraku, a od połowy drugiej dekady władze RP preferują rozwijanie zdolności defensywnych, mających zwiększyć skuteczność obrony kolektywnej Sojuszu. Niestety koncepcje te dotychczas nie przełożyły się na w wymiarze praktycznym na zwiększenie tempa modernizacji Sił Zbrojnych RP.

25 Przykładem takiego zaangażowania z udziałem m. in. kontyngentów amerykańskich i polskich może być operacja ISAF w Afganistanie, gdzie brak określenia realnego/wykonalnego finalnego celu strategicznego w wymiarze politycznym i gospodarczo-społecznym, przyczynił się do jej niepowodzenia i zakończenia w roku 2014.

26 Szanse strategiczne - niezależne od woli podmiotu okoliczności (zjawiska i procesy w środowisku bezpieczeństwa) sprzyjające realizacji interesów oraz osiąganiu celów podmiotu w dziedzinie bezpieczeństwa, Biała księga..., s. 248. 
10. Zwiększenie znaczenia Polski w środowisku międzynarodowym za sprawą ścisłego współdziałania $\mathrm{z}$ USA w procesie stabilizacji sytuacji bezpieczeństwa w różnych regionach i państwach (np. na Bałkanach);

11. Zwiększenie poziomu bezpieczeństwa RP i wschodniej flanki NATO poprzez: obecność wojsk Sojuszu, w tym głównie sił amerykańskich na terytorium Polski, ćwiczenia sojusznicze, plany zakupu nowych systemów uzbrojenia, inwestycje offsetowe, możliwości transferu technologii ${ }^{27}$, wymianę informacji;

12. Transformacja Sił Zbrojnych RP, pozwalająca na realne i systemowe rozwijanie militarnych zdolności w wymiarze narodowym i wielonarodowym we współpracy z partnerem amerykańskim;

13. Rozwój infrastruktury szkoleniowej i obronnej państwa, co ma pozytywny wpływ na poziom przygotowywanych zasobów osobowych oraz zwiększanie liczby i jakości obiektów wykorzystywanych w systemie obronnym państwa i sojuszu;

14. Rozmieszczenie na terytorium Polski struktur wielonarodowych powiązanych z NATO pozwalających na podnoszenie poziomu interoperacyjności działań sojuszniczych, w większości których kluczową rolę pełnią żołnierze amerykańscy;

15. Współorganizacja sojuszniczych ćwiczeń na terytorium RP, czego potwierdzeniem może być przeprowadzanie co roku na terytorium Polski wielonarodowych ćwiczeń „Anakonda”, z licznym udziałem sił amerykańskich;

16. Inicjatywa sił połączonych (od 2012 - utrzymanie i rozwój interoperacyjności sił sojuszniczych, po zakończeniu operacji ISAF w 2014 r.);

17. Rozwój poszczególnych rodzajów wojsk, czego przykładem są polskie siły specjalne oraz Dowództwo Komponentu Wojsk Specjalnych w Krakowie, które uzyskało zdolność do dowodzenia komponentami sił specjalnych państw NATO, w których wiodącą rolę pełnią amerykańskie siły specjalne;

18. Podnoszenie poziomu interoperacyjności Wojska Polskiego z innymi państwami członkowskimi sojuszu, szczególnie USA - poprzez wspólną

27 O ile organy i podmioty państwowe odpowiedzialne za realizację kolejnych planów modernizacji technicznej Sił Zbrojnych RP (pierwszy z roku 2013, a ostatni na lata 2017-2026) przejdą z etapu deklaracji, dokonywania radykalnych zmian i podpisywania umów - do etapu ich stopniowego i konsekwentnego wdrażania. 
realizację zadań w ramach operacji międzynarodowych (np. pokojowych, stabilizacyjnych), ćwiczeń, służby w sztabach wielonarodowych;

19. Rozwój współpracy polityczno-militarnej w regionie Europy Środkowo-Wschodniej w ramach wspólnych inicjatyw i projektów (np. BALTIC AIR POLICING, JFTC, 3NSB, MP COE);

20. Zacieśnianie współpracy $\mathrm{w}$ obszarach bezpieczeństwa politycznego, ekonomicznego i militarnego ze Stanami Zjednoczonymi (zwiększanie rotacyjnej obecności sił amerykańskich w Polsce, inwestycje w infrastrukturę wojskową, wspólne szkolenia, inwestycje amerykańskie w polski przemysł zbrojeniowy).

\section{PODSUMOWANIE}

Do pozytywnych efektów realizacji zasadniczych celów strategicznych w obszarze polskiej polityki bezpieczeństwa w ostatniej dekadzie XX i pierwszej dekadzie XXI w. można zaliczyć: członkostwo w Sojuszu Północnoatlantyckim (1999); partnerstwo strategiczne ze Stanami Zjednoczonymi; nawiązanie i kontynuacja współpracy subregionalnej (Grupa Wyszehradzka, Inicjatywa Środkowoeuropejska, Rada Państw Morza Bałtyckiego, Trójkąt Weimarski); zaangażowanie w operacje wsparcia pokoju prowadzone przez NATO (Bośnia i Hercegowina, następnie Kosowo od 1999); podniesienie poziomu interoperacyjności SZ RP. Z kolei do celów, których nie udało się osiągnąć należy zaliczyć: deficyt sukcesów w sferze prowadzenia stabilnej polityki wobec Rosji (zwłaszcza w obszarze niemilitarnych aspektów bezpieczeństwa - energetyka, polityka historyczna); pogorszenie stosunków z Białorusią; stopniowe zmniejszenie liczebności SZ RP; restrukturyzacja WP; permanentna reforma szkolnictwa wojskowego; problemy z wymianą zużytego sprzętu wojskowego (w wymiarze ilościowym i jakościowym) (Biała księga..., s. 35).

Należy podkreślić, iż w latach 90. polskie kontyngenty wojskowe prowadziły dwa zasadnicze rodzaje działań w ramach operacji pokojowych i stabilizacyjnych, a mianowicie realizowały zadania logistyczne oraz mandatowe zadania operacyjne, stanowiące nowy dla pododdziałów polskich rodzaj aktywności wojskowej. Od 1991 roku kontyngenty Wojska Polskiego brały udział w operacjach pokojowych i stabilizacyjnych prowadzonych pod przywództwem Stanów Zjednoczonych (Zatoka Perska, Haiti, Bałkany). Po przystąpieniu Polski do NATO, na co znaczący wpływ miało wsparcie ze strony USA, współpraca pol- 
sko-amerykańska była nadal rozwijana zarówno w ramach międzynarodowych operacji sojuszniczych (Bałkany - SFOR, KFOR; Afganistan - ISAF, Resolute Support; Irak - NTCB-I), jak i koalicyjnych (Afganistan - Enduring Freedom; Irak - Iraqi Freedom - nie mających podstaw prawnych uznawanych przez społeczność międzynarodową).

Należy dodać, iż zaangażowanie żołnierzy i kontyngentów Wojska Polskiego w okresie członkostwa Polski w Sojuszu Północnoatlantyckim (od 1999) w ramach wielonarodowych operacji pokojowych i stabilizacyjnych warunkowało wykonywanie takich przedsięwzięć między innymi, jak: kontynuowanie wcześniejszych zadań operacyjnych (SFOR - Bośni i Hercegowinie do 2004 roku, KFOR - w Kosowie do chwili obecnej); wykonywanie zadań bojowych w ramach operacji koalicyjnych w Iraku (Iraqi Freedom 2003-2008) oraz Afganistanie (ISAF 2007-2014); szkolenie lokalnych sił bezpieczeństwa (Irak, Afganistan, Kosowo); ochrona granic powietrznych państw sojuszniczych (Litwa, Łotwa, Estonia), wsparcie ochrony wschodniej flanki sojuszu (Łotwa, Rumunia, Bułgaria). W ramach znaczącej większości tych działań żołnierze i polski personel cywilny współpracowali na różnych szczeblach z wojskowo-cywilnym składem komponentów amerykańskich.

Podsumowując, należy podkreślić, iż znaczące zaangażowanie Polski w międzynarodowe operacje pokojowe i stabilizacyjne prowadzone pod przywództwem Stanów Zjednoczonych lub podczas których kluczową rolę polityczno-militarną odgrywało to mocarstwo, zazwyczaj miało i ma pozytywny wpływ na wizerunek Polski jako wiarygodnego członka Sojuszu oraz podnosi realny poziom interoperacyjności Sił Zbrojnych RP. Warto jednak dodać, iż nadgorliwe i bezkrytyczne angażowanie Sił Zbrojnych RP w operacje koalicyjne pod przywództwem USA (Afganistan - 2002; Irak - 2003), które nie miały podstawy prawnej i akceptacji społeczności międzynarodowej (np. w formie rezolucji Rady Bezpieczeństwa ONZ), negatywnie wpływało na relacje z wieloma państwami sojuszniczymi (Niemcy, Francja), jak i nie znajdowało zrozumienia i poparcia społecznego w Polsce ${ }^{28}$.Zatem należy podkreślić, iż zaangażowanie państwa polskiego i jego sił zbrojnych w operacje międzynarodowe prowadzone pod przywództwem Stanów Zjednoczonych powinno być zgodne z prawem międzynarodowym,

28 W latach 2004-2008 ponad 80\% społeczeństwa polskiego było przeciwne zaangażowaniu Wojska Polskiego w działania stabilizacyjne w Republice Iraku, CBOS badania za lata 2004-2008. 
celami strategicznymi Sojuszu Północnoatlantyckiego oraz polskimi interesami narodowymi postrzeganymi, co najmniej w średnio i długookresowej perspektywie strategicznej.

\section{BIBLIOGRAFIA:}

Biała ksiegga bezpieczeństwa narodowego Rzeczypospolitej Polskiej (2013). Warszawa: Wyd. BBN.

Ciechanowski, G. (2010). Polskie Kontyngenty Wojskowe w operacjach pokojowych 1990-1999, Toruń: Wydawnictwo Adam Marszałek.

Kozerawski, D. S. (red.) (2007). Działania wojenne, pokojowe i stabilizacyjne prowadzone $w$ warunkach szczególnych w XX i XXI wieku, Konflikty-doświadczenia-bezpieczeństwo. Toruń: Wydawnictwo Adam Marszałek.

Gall, S. (2012). War against the Taliban. Why it all went wrong in Afghanistan, London: Bloomsbury Publishing.

Gągor, F., Paszkowski, K. (1999). Międzynarodowe operacje pokojowe w doktrynie obronnej RP. Toruń: Wydawnictwo Adam Marszałek.

Gilman, W. E., Herold D. E. (1994) Peacekeeping Challenges to Euro-Atlantic Security, Rome: ed. NATO Defence College.

Hillen, J. (1998). Blue Helmets - the strategy of UN military operations. London.

Hudson, M. C. (2009). The United States in the Middle East. W: L. Fawcett (red.). International Relations of the Middle East, Oxford University Press.

Irwin, L. G. (2012). Disjointed Ways, Disunified Means: Learning from America's Struggle to Build an Afghan Nation, Carlise Barracks: U.S. Army War College.

Jureńczyk, Ł. (2016). Polska w Sojuszu Pótnocnoatlantyckim. Wojsko Polskie w operacji reagowania kryzysowego NATO. Bydgoszcz: Wydawnictwo Uniwersytetu Kazimierza Wielkiego.

Kozerawski, D.S. (2021). Polskie kontyngenty wojskowe na wschodniej flance NATO a wzmocnienie systemu bezpieczeństwa w wymiarze lokalnym i regionalnym. W: P. Bajor (red.). Bezpieczeństwo regionalne. Węzłowe problemy i procesy (ss. 93-108). Kraków: Wyd. WUJ.

Kozerawski, D.S. (2018). Działania pokojowe i stabilizacyjne w polskiej polityce bezpieczeństwa - skutki i perspektywy. W: H. Ćwięk, M. Siewier (red.). Bezpieczeństwo Polski w XX i XXI wieku (ss. 127-141). Częstochowa: Uniwersytet Humanistyczno-Przyrodniczy.

Kozerawski, D.S. (2018). The Gender issue in the Polish Armed Forces on the Example of Peace and Stabilization Operations. Science and Military, 1, 55-61, Liptovsky Mikulaś.

Kozerawski, D.S. (2015). Military Contingents' participation in UN peace operations during the Cold War time. Using the past to keep peace the present. W: H. E. Raugh (red.). Doctrinal Change: Using the past to Weight the present (ss. 78-93). Bratislava.

Kozerawski, D. S. (2014). Polish Military-Civilian Contingents' Participation in Stabilization and Peace Process in Middle East in the Cold War Time. Political-Strategic 
and Operational Tasks Conducting. W: Poland - Visegrad Group - Jordan (ss. 78-93). Amman.

Kozerawski, D. S. (2014). Multi-nationality as a Strategic Challenge for Coalition Operations: A Case Study of Polish Military Contingent Experience in Iraq, 2003-2008. W: Nations at War; Why do Nations Participate in War and Why Not? (ss. 78-93). Sofia.

Kozerawski, D. S. (2013). Theory versus Realism - The Use of the Soviet Strategy and the Antiterrorism Coalition Strategy in the 1979-2012 Wars Afghanistan Wars. W: Past through Present: Thoughts on Military History at the Strategic, Operational and Tactical Levels of War (ss. 223-237). Vienna.

Kozerawski, D. S. (2012). Kontyngenty Wojska Polskiego w międzynarodowych operacjach pokojowych w latach 1973-1999. Konflikty - interwencje - bezpieczeństwo, Torun: Wydawnictwo Adam Marszałek.

Kozerawski, D. S. (2012). Irregular Warfare as a Primary Threat to Multinational Stabilization Forces in Afghanistan (2002-2011). W: Regular and Irregular Warfare: Experiences of History and Contemporary Armed Conflicts (ss. 167-178). Belgrade: Institute for Strategic Research.

Kozerawski, D. S. (2011) Multiculturalism in the Multinational Division Central-South international stability operations in Iraq (2003-2008). Science and Military, 1, Liptovsky Mikulaś.

Kozerawski, D. S. (2010). Konflikty zbrojne drugiej połowy XX wieku i ich wpływ na rozwój sztuki wojennej, W: R. Łoś, J. Reginia-Zacharski (red.). Konflikty zbrojne i spory międzynarodowe. T. 2. Łódź: Wydawnictwo Uniwersytetu Łódzkiego.

Kozerawski, D. S. (2010). Międzynarodowe działania stabilizacyjne w świetle doświadczeń X zmiany PKW Irak w 2008 roku, Warszawa: National Defence University Press.

Kozerawski, D.S. (2009). Polish Military Contingents in International Peacekeeping and Stabilization Operations between 1973 and 2009. W: H. E. Raugh (ed.), End of Empires. Challenges to Security and Statehood in Flux, Bucharest: Institute for Political Studies of Defence and Military History, Ministry of Defence Press.

Kukułka, J. (2007). Historia współczesna stosunków międzynarodowych 1945-2000. Warszawa.

Raugh, H. E. (ed.). (2003). Międzynarodowe operacje pokojowe. Planowanie, zadania, warunki i sposoby realizacji. Warszawa: National Defence University Press.

Kozerawski, D.S. (red.). (2010). Military Conflicts in the $20^{\text {th }}$ Century - Political and Military Aspects. Warszawa: National Defence University Press.

Kozerawski, D.S. (red.). (2006). Operacje pokojowe $i$ antyterrorystyczne $w$ procesie utrzymania bezpieczeństwa międzynarodowego w latach 1948-2004, Toruń: Wydawnictwo Adam Marszałek.

Daniel, D.S.F., Taft, P., Wiharta, S. (red.). (2008). Peace Operations. Trends, Progress, and Prospects. Washington: Georgetown University Press.

Haliżak, E. i inni (red.). (2019). Polska $w$ instytucjach międzynarodowych $w$ latach 1918-2018. Warszawa: Wyd. Narodowe Centrum Kultury.

Kozerawski, D. S. (red.). (2004). Udział jednostek Wojska Polskiego w międzynarodowych 
operacjach pokojowych w latach 1973-2003. Warszawa: National Defence University Press.

Kozerawski, D.S. (red.). (2011). Wojsko Polskie w międzynarodowych operacjach pokojowych i stabilizacyjnych. Konflikty - spory - bezpieczeństwo. Warszawa: National Defence University Press.

Zając, J., Zięba, R. (2007). Polska w stosunkach międzynarodowych 1945-1989. Toruń: Wydawnictwo Adam Marszałek. 